\title{
Marketised private tutoring as a supplement to regular schooling: \\ Liberal Studies and the shadow sector in Hong Kong secondary education
}

\author{
CLAUdiA CHAN and MARK BRAY
}

\begin{abstract}
Around the world, increasing numbers of students receive after-school private supplementary tutoring. Such tutoring may be provided through informal channels or by companies; and it may be received one-to-one, in small groups, or in large classes. The tutoring is commonly called shadow education since its content mimics that of regular schooling. The spread of shadow education is part of a global shift of balance with increased roles for the private sector.

Hong Kong is among the societies in which shadow education enrolment rates are particularly high. Much shadow education focuses on techniques for performance in external examinations, and is not consistent with the emphases stressed by teachers and the government. This paper focuses on a newlyintroduced subject called Liberal Studies in which the tensions are especially visible. Although the official curriculum emphasises creativity and critical thinking, many students have sought large-class tutoring focused on formulae for passing examinations. Interviews exposed the needs that the students felt were not being met in their schooling. The findings illustrate some of the complexities in relationships between the public and private sectors. Viewed in a wider context, the paper illuminates some of the mechanisms and effects of marketisation which are increasingly evident globally.
\end{abstract}

Keywords: marketisation, private tutoring, shadow education, Liberal Studies, educational reform

\section{Introduction}

Private supplementary tutoring, in which students pay for additional assistance outside formal school hours, is widely called shadow education (see e.g. Aslam and Atherton 2012; Bray 1999; Bregvadze 2012; Lee et al. 2009). The metaphor is used because much of the tutoring content mimics that of regular schooling: as the curriculum in regular schooling changes, so it changes in the shadow. Also, as regular school systems expand, so does the shadow.

Shadow education has long been extensive in much of East Asia (see e.g. Stevenson and Baker 1992; Zeng 1999), and has now become a global phenomenon (Bray 2009; Mori and Baker 2010; Southgate 2009). Researchers and policy makers increasingly recognise the significance of shadow education, and take it into 
consideration when evaluating cross-national data on educational achievement (see e.g. Askew et al. 2010; Song et al. 2013), equitable access to quality education (e.g. UNESCO 2012: 76), and the lives of students, teachers and families (e.g. Buhagiar and Chetcuti 2013; Sobhy 2012).

A major objective for one group of researchers on shadow education is to expose the hidden implications of marketisation of education (see e.g. Silova et al. 2006; Privatisation in Education Research Initiative 2013). The present paper contributes to that objective. Shadow education is part of a global shift of balance between public and private in the education sector. Some students are pushed towards shadow education by a feeling that schooling is not meeting all of their needs, and other students are pulled towards shadow education by the marketing of the shadow education providers.

The paper focuses on Hong Kong, where private supplementary tutoring has greatly expanded in both scope and intensity since the mid-1990s, and has become a visibly marketised sector alongside and interacting with the public schools (Kwo and Bray 2011; Kwok 2004, 2009; Lee 1996). A 2011/12 survey indicated that $53.8 \%$ of Grade 9 students and $71.8 \%$ of Grade 12 students received private supplementary tutoring (Zhan et al. 2014). The paper exposes patterns in Hong Kong that are likely to have parallels elsewhere; and insofar as shadow education in other societies is expanding towards the proportions already reached in Hong Kong, analysis of the Hong Kong patterns may provide a signal about features that are likely to become more evident elsewhere.

The forms of tutoring include one-to-one provision, small groups, and large classes. In Hong Kong, the market for senior secondary students is dominated by commercial operators that have multiple outlets and mainly offer large classes. These companies organise both live and video tutorials, and attract clients through advertising and flashy images of "star tutors" (Kwo and Bray 2011; Zhan et al. 2014). The companies that serve the senior secondary sector emphasise ways to approach watershed examinations, and some of their classes have over 100 students. Many school teachers, government personnel and members of the general public criticise these mass tutorial schools due to their commercial images and their educational approaches which stress scoring in examinations rather than wider processes of education (see e.g. Ngai et al. 2013: 3839). Nevertheless, the approaches are undeniably attractive to the companies' teenage clients.

This paper begins by elaborating on the nature of privatisation in the education sector and on the scale and implications of shadow education around the world. It then turns to Hong Kong, providing background information on the government's aspirations to reform teaching and learning approaches, and elaborating on the philosophy and approaches of the Liberal Studies curriculum. Next the presentation turns to methodology, explaining the basis for the remarks that follow. The core of the paper lies in interview data from 16 students who were receiving tutoring from commercial companies. The principal descriptive questions were:

- What needs did the students perceive which were not being met by their schools and which they felt could be met by the tutoring companies?

- What impact did the activities in the shadow sector have on approaches to learning, schooling experiences, and wider values? 
The commentary includes comparison of the students' perceptions of their school classes and tutorial classes, and notes ways in which the tutoring companies created perceptions of needs. The concluding parts of the paper link back to the wider picture to show how patterns in Hong Kong may have relevance to other parts of the world. This includes remarks not only on the spread of shadow education and the shifting roles of the state and private sector, but also on the obstacles to change at the classroom level of the type envisaged by the government reformers.

\section{Global Policy Shifts and Implications of the Expansion of Shadow Education}

This paper is contextualised within global shifts in modes of financing of education. These shifts are part of the rise of neoliberalism, i.e. a set of macro-economic policy approaches that became prominent in some locations during the 1980s and subsequently spread across the world (Harvey 2007; Steger and Roy 2010). Some authors have linked neoliberalism to what they call the Washington Consensus, stressing features that include privatisation of service-delivery and reduction of taxation and government subsidies. The author of the Washington Consensus terminology has highlighted ways in which much discussion has departed from his original set of ideas (Williamson 2009). Similarly, the terminology of neoliberalism is used in ways that are not always consistent across diverse contexts (Harvey 2007; Steger and Roy 2010). Nevertheless, core elements of the neoliberal approach have been evident worldwide in education as well as other sectors. They have included a contraction in the role of the state and a corresponding expansion in the role of the private sector (Lakes and Carter 2011; Torres 2009). Advocates of a greater market role in education have argued that marketisation can enhance efficiency in operation and accountability to consumers. Critics underline what they see as the inequities exacerbated by marketisation and the distortion of some fundamental purposes of education (Apple 2006; Ward 2013; Zajda 2006).

Ball and Youdell (2008) identified two categories of privatisation in the education sector, which they labelled endogenous and exogenous. In the first category, schools become more business-like, for example introducing performance-related pay and viewing students as clients to be sought and satisfied. In the second category are initiatives that bring the private sector into public schools through contracting out specific services or whole institutions, and operating public-private partnerships of various kinds. Ball and Youdell only made two passing references to the focus of the present paper, i.e. private tutoring, but they noted that parents are commonly persuaded to invest in tutoring, to purchase educational toys, and to buy publications on how to perform their roles better. Ball and Youdell observed (p.98) that the market in education "is no longer simply a matter of choice and competition between educational institutions but rather is a diffuse, expanding, and sophisticated system of goods, services, experiences and routes - publicly and privately provided”. Along the same lines, Mazawi (2013: 45) noted that "the public and private sectors are intertwined along complex articulations”.

The fact that shadow education received so little attention in Ball and Youdell's (2008) report might have surprised some readers. The report was entitled Hidden Privatisation in Public Education, and perhaps the phenomenon was still largely hidden - at least from these authors based in Europe. However, as noted 
above, shadow education has long been a major phenomenon in East Asia; and a growing body of research shows that the sector has become extensive in Europe, among other regions (Bray 2011; Bray et al. 2013; Ireson and Rushforth 2001; Safarzyńska 2013). Insofar as current patterns in Asia may signal a future for Europe and elsewhere, they deserve wide attention.

Elaborating, studies of shadow education in Asia include Kim's (2010: 302) report from Korea, which indicated that $88 \%$ of elementary students, $72 \%$ of middle school students, and $60 \%$ of general high school students were estimated to be receiving tutoring in 2008. In Japan, a 2007 survey found that $65 \%$ of Secondary 3 students attended supplementary institutions known as $j u k u$, a further $7 \%$ received tutoring at home, and 15\% followed correspondence courses (Japan 2008: 13). And in China, a 2010 survey of Grade 12 students in Jinan found that 48.6\% were receiving private tutoring (Zhang 2011: 111). Other studies show significant and growing volumes of shadow education in countries as diverse as Cambodia, India, Malaysia, and Mongolia (Bray and Lykins 2012).

The fact that such high figures have been reported for several decades especially in Korea, Japan and other parts of East Asia explains why shadow education has been particularly associated with that region. Nevertheless, significant numbers are also found elsewhere. In Egypt, for example, Sobhy (2012: 49) highlighted a survey showing that $81 \%$ of households with children attending secondary school had paid for tutoring. In Greece, Kassotakis and Verdis (2013: 99) estimated that 59\% of secondary grammar school students enrolled in tutorial centres, and that additional numbers received one-to-one tutoring of various types. Other studies have shown substantial shadow education enrolments and significant expansion in Africa (e.g. Napporn and Baba-Moussa 2013; Odhiambo 2009), Eurasia (e.g. Silova 2010; Silova et al. 2006), North America (e.g. Burch 2009; Davies and Guppy 2010), and South America (e.g. Gomes et al. 2010; Ventura and Gomes 2013).

The issues associated with this phenomenon are many and varied. Most obvious, alongside other dimensions of marketisation associated with neoliberal policies, are those which concern equity since prosperous households can invest in more and better private tutoring than middle-income and poor households. At the official level, schooling is commonly described as fee-free and equitable; yet behind this façade, households may find themselves forced to invest in shadow education if they do not wish to be left behind in the competitive system. Diskin (2010), following Bourdieu (1998), Putnam (2000) and others, is among authors who have highlighted the roles of economic interests and social capital in these processes.

A second issue, more pertinent to the present paper and arguably related, concerns teachers' attitudes. When shadow education becomes widespread, teachers may feel that their students have a safety net outside the school and therefore that the teachers do not need to work as diligently as they might when shadow education is not common. The public sector shrinks in its roles, and allows or invites markets to fill the resulting gaps. The shifting balances also bring changes in students' expectations that have further backwash effects on regular schooling. In particular, students may reduce their respect for and reliance on their teachers and school curriculum, and instead place more emphasis on the shadow sector. 
Further, as illustrated in the present paper, shadow education may undermine aspects of educational reform. Governments around the world emphasise creativity and independent learning in the goals of their education systems, but shadow education may have very different values and orientations. This is especially obvious in the 'cram' schools of such countries as Turkey, Greece and Japan (Baştürk and Doğan 2011; Kassotakis and Verdis 2013; Roesgaard 2006), though of course much depends on the precise types and modes of operation of the shadow education institutions.

More positively, supplementary tutoring in the marketplace may be more client-oriented than regular schooling. Teachers in public schools can to some extent ignore their students' desires and perceived needs because schooling is free of charge and compulsory. The students have little choice in who teaches them for particular subjects, and have few channels to express their preferred styles of learning. In the marketplace, by contrast, the students can choose their tutors, who in turn take care to be responsive to perceived needs in order to attract more students. Policy makers who are concerned that public schooling is insufficiently sensitive to students may look at the supplementary sector for innovative ideas and client-oriented approaches. However, policy makers are likely to recognise that schooling serves broader functions than supplementary tutoring, including dimensions of moral development and socialisation. The question then becomes one of differential roles between public and private sectors. Sometimes this causes tension, especially when the marketisation undermines aspects of regular schooling.

\section{Educational Reform in Hong Kong}

In a set of education reforms launched at the turn of the century, the Hong Kong government has endeavoured to change what it perceives as the deep-rooted examination-oriented approach to learning. The foundation reform document (Education Commission 2000) was entitled Learning for Life, Learning through Life. It expressed determination to divert students from learning for examinations, and stressed the importance of learning to learn. Subsequently, the whole structure of secondary education was changed. The government abolished the ' $5+2+3$ ' system, i.e. five years of lower secondary leading to the Hong Kong Certificate of Education Examination (HKCEE), two years of matriculation education leading to the Hong Kong Advanced Level Examination (HKALE), and three years for a basic university degree. The structure was replaced by a ' $3+3+4$ ' system, i.e. three years of junior secondary without any external public examination, three years of senior secondary education leading to the Hong Kong Diploma of Secondary Education (HKDSE) examination, and four years for a basic university degree. The first cohort in the new system commenced its Grade 10 studies in 2009/10, and reached Grade 12 for the first HKDSE examination in 2011/12. Some of the students whose experiences are reported in this paper were participants in this first cohort, while others were in the following two cohorts.

In addition to changing the overall structure, the Hong Kong government reformed the curriculum. Four subjects were made compulsory for senior secondary education, namely English, Chinese, Mathematics, and Liberal Studies. This paper focuses on the last of these. Liberal Studies had long been taught in some secondary schools as an option both in lower grades and in higher grades for the Hong Kong Advanced 
Supplementary Level (ASL) examination, but was reshaped and made compulsory for all senior secondary students (Grades 10-12) in the new system with effect from 2009 (Fung and Yip 2010).

Liberal Studies was regarded as the embodiment of the education reform because it emphasised critical thinking and flexible application of knowledge in contrast to rote memorisation of fixed content (Deng 2009; Fung et al. 2011). Students' active participation was stressed, and Liberal Studies teachers were encouraged to adopt an issue-enquiry learning approach. Yet despite this design, mass tutorial companies rapidly developed offer of classes in Liberal Studies alongside other subjects. A local newspaper reported in 2011 that although Liberal Studies was designed for a style which contrasted with the norm in the masstutorial classes, over 10\% of senior secondary students had enrolled in such classes (Poon 2011). A separate survey of Grade 12 students in 14 local-curriculum secondary schools in 2011/12 found that 16.6\% were receiving tutoring in Liberal Studies (Bray et al. 2012). Among the students receiving such tutoring, 71.8\% did so in large video-recorded classes, and $59.0 \%$ did so in live lecture-style classes. At $16.6 \%$, the proportion of students receiving tutoring in Liberal Studies was much less than the $80.3 \%$ in English, $40.5 \%$ in Chinese and $29.4 \%$ in Mathematics, but was arguably still a large proportion given that the architects of the Liberal Studies curriculum had actively sought to steer students away from such activity.

Also important to mention are policies on the medium of instruction. In Hong Kong, both English and Chinese are official languages. Some schools teach in English (except for classes in Chinese language), some teach in Chinese (apart from classes in English language), and some use different languages for different classes and/or subjects (Morris and Adamson 2011: 147-160). English is widely considered to be prestigious and desirable for future labour-market mobility, even if less convenient for learning by those for whom it is not the mother tongue. This is another domain in which private tutoring provides a service - assisting students whose school curriculum is in one language but who desire support through the other language.

\section{Liberal Studies Approaches and Assessment}

The philosophy of the Liberal Studies curriculum is reflected in the name of the subject itself. As pointed out by Deng (2009: 688), the subject 'aims at liberating the minds of students by providing them with opportunities to explore a wide range of contemporary issues of social and personal significance from multiple perspectives, and to develop problem-solving and critical thinking capacities'. The curriculum is based on a constructivist approach to learning and teaching (Ng 2006), and its architects intended direct teaching and rote memorisation to be replaced by students' active participation and social interaction. As explained in the Curriculum Guide (Curriculum Development Council [CDC] and Hong Kong Examinations and Assessment Authority [HKEAA] 2007: 2), Liberal Studies 'enables students to make connections among different disciplines, examine issues from a variety of perspectives, and construct personal knowledge of immediate relevance to themselves in today's world.' The architects of the curriculum expected that as students gained the competence to learn independently, teachers would go beyond their roles as facilitators to become equal members in the learning community (CDC and HKEAA 2007: 105). Table 1 indicates the structure and contents of the syllabus. The types of interactive learning strategies envisaged by the official Curriculum 
Guide, such as role-play, debate and group discussions, were in sharp contrast to the type of pedagogy that characterised the mass tutorial centres. Those settings were dominated by direct instruction and focus on the tutors.

Table 1: The Liberal Studies Syllabus

\begin{tabular}{|c|c|}
\hline $\begin{array}{l}\text { Areas of Study } \\
\end{array}$ & Independent Enquiry Study (IES) \\
\hline $\begin{array}{r}\text { Self \& Personal Development } \\
\text { - } \quad \text { Module 1: Personal Development and } \\
\text { Interpersonal Relationships }\end{array}$ & $\begin{array}{l}\text { Students are required to conduct an IES making use of the } \\
\text { knowledge and perspectives gained from the three Areas } \\
\text { of Study and extending them to new issues or contexts. }\end{array}$ \\
\hline $\begin{array}{l}\text { Society \& Culture } \\
\text { - } \quad \text { Module 2: Hong Kong Today } \\
\text { - } \quad \text { Module 3: Modern China } \\
\text { - } \quad \text { Module 4: Globalization }\end{array}$ & $\begin{array}{l}\text { To help students develop their IES titles, the following } \\
\text { themes are suggested: } \\
\text { - Media } \\
\text { - Education }\end{array}$ \\
\hline $\begin{array}{l}\text { Science, Technology \& the Environment } \\
\text { - Module 5: Public Health } \\
\text { - Module 6: Energy, Technology \& the } \\
\text { Environment }\end{array}$ & $\begin{array}{l}\text { - Religion } \\
\text { - Sports } \\
\text { - Art } \\
\text { - Information and Communication Technology (ICT). }\end{array}$ \\
\hline
\end{tabular}

Source: CDC and HKEAA (2007: 11).

For assessment of Liberal Studies, a combination of School-Based Assessment (SBA) and written examinations was prescribed. Table 2 indicates the weightings. SBA was considered a relatively reliable indicator of the students' actual abilities and development in the affective domain (CDC and HKEAA 2007; Fung et al. 2011). The long-term assessment permitted by SBA was also expected to reduce the emphasis on one-off public examinations. Since mass tutoring companies exploit students' anxiety about high-stakes examinations to secure and expand their markets, the introduction of SBA was expected to reduce the stress on such tutoring.

Table 2: Assessment Weightings in the Liberal Studies Curriculum

\begin{tabular}{|l|l|c|l|l|}
\hline Component & Part & Weighting & Duration & Features \\
\hline $\begin{array}{l}\text { School- } \\
\text { based } \\
\text { assessment }\end{array}$ & $\begin{array}{l}\text { Independent } \\
\text { enquiry study }\end{array}$ & $20 \%$ & $\begin{array}{l}\text { Two years } \\
\text { Three stages for: } \\
\text { - project proposal, } \\
\text { - data collection, } \\
\text { - product }\end{array}$ & $\begin{array}{l}\bullet \text { students to experience self-directed, } \\
\text { enquiry learning } \\
\text { students to draw links between } \\
\text { knowledge across the curriculum } \\
\text { students to develop their higher- } \\
\text { order thinking skills }\end{array}$ \\
\hline $\begin{array}{l}\text { Public } \\
\text { examination }\end{array}$ & $\begin{array}{l}\text { Paper I: Data } \\
\text { response questions }\end{array}$ & $50 \%$ & 2 hours & $\begin{array}{l}\text { testing a representative sample of } \\
\text { the broad learning outcomes and } \\
\text { assessment objectives } \\
\text { cross-disciplinary context } \\
\text { allow differentiation in levels of } \\
\text { performance }\end{array}$ \\
\cline { 2 - 5 } & $\begin{array}{l}\text { Paper II: } \\
\text { Extended-response } \\
\text { questions }\end{array}$ & $30 \%$ & 1 hour 15 minutes & \\
\hline
\end{tabular}

Source: CDC and HKEAA (2007: 130); HKEAA briefing session documents. 
Although SBA was a significant innovation, table 2 shows that the examinations still comprised $80 \%$ of the total assessment. However, reforms were announced in the nature of the examinations. The authorities indicated that they would test students' thinking skills instead of their memorised knowledge, demanding responses on the students' opinions and judgements about current issues rather than a fixed body of content. The reformers promised open-ended questions to match the issue-enquiry pedagogy. Focus was then to be on students' exemplification of flexible thinking skills. As explained by the CDC and HKEAA (2007: 130):

The question format [of the examination] is not meant to imply that students have to identify certain correct answers - on the contrary, the approach used stresses that most issues are too complex to allow of simple solutions. Although, of course, one needs to have knowledge of relevant facts in order to make judgments about issues, the examination will not focus on factual knowledge - indeed great care will be taken to avoid questions which call for detailed factual recall.

In addition, standard-referenced reporting of assessment results was expected to curb students' enrolment in mass tutorial classes where teaching and learning emphasised competition among peers more than personalised learning and group work. The standard-referenced reporting evaluated students' performance against level-descriptive marking rubrics rather than ranking among peers. The aim was to foster an atmosphere of learning for enrichment rather than competition (CDC and HKEAA 2007: 130-131).

\section{Methods}

Because the research on which this paper reports aimed to understand first-person perceptions, qualitative data from interviews were the chief component. One author was a secondary school teacher, and the other was employed by a university. Within the university framework, the research design and instruments were reviewed and approved by an Ethics Committee. Data were collected first in one school in which the firstnamed author was a Liberal Studies teacher, and then in a second school after she had moved to a new post. One school served medium and low achievers (Bands 2 and 3 in the Hong Kong system), and the other served high achievers (Band 1). Thus, the ability grouping was across the range, and permitted insights into different types of students.

In the first school, semi-structured interviews were conducted with six students. The process began with three students who had previously been taught by the first-named author and were known to be receiving tutoring from a mass-tutoring company. Interviewees were added with a 'snowball' sampling technique (Johnson and Christensen 2012: 231), i.e. identification by these students of peers who also received mass tutoring. Each student was first interviewed separately and then again in a group. Experience showed that sometimes students were stimulated by group discussions to become more forthcoming, but that sometimes students were shy to speak about their motives and experiences in front of peers. The combination of both individual and group interviews was therefore productive not just for triangulation but also for elaboration. The fact that the researcher taught in the school and was thus part of the environment was an advantage. Sikes and Potts (2008: 177) have noted that insider research can be complex, but that when it works well it can be 
very productive for example because "inside researchers readily know the language of those being studied along with its particular jargon and meanings [and] are more likely to understand the events under investigation". Although three of the six students had been taught by the researcher in the past, none were being taught by the researcher at the time of the research. She was mindful of the need to conduct her work "perspectively" rather than subjectively (Osborne 1990), and was conscious of the dynamics inherent in interaction between an adult teacher and teenage students. The core foci of the interviews were why students sought tutoring; how they compared their Liberal Studies experiences in school and tutorial centres; and what they most liked and disliked in the respective classes. The interviews were recorded, transcribed verbatim and then coded. They were first read inductively and then read again to identify emergent categories. These categories were further shaped by reference to the literature and to quantitative data not reported here.

In the second school, semi-structured interviews were conducted with 10 students. The questions were similar to those asked in School A, and again a snowballing approach was used. Initially, six students were interviewed individually or in groups. The balance between individual and group interviews was determined by the preferences of the students themselves. Among the 10 students in School B, the researcher had been teacher of four and was still teacher of two of these four. She had a good relationship with these two, and they indicated that they were comfortable to express their views. The others were students in classes that had not been taught by the researcher, and she did not therefore have the same type of relationship. For this reason she chose a group interview in the hope that the students would be stimulated by the responses of their peers. Care naturally had to be taken in both body language and spoken interaction during the interviews, especially when the students were commenting on the teaching styles of either the researcher or a colleague. These matters had been considered by the researcher in advance, and she is confident that on balance the benefits from having been an insider in the schools outweighed those of being an outsider. At the same time, the research design, processes and analysis benefited from discussions at every stage with the co-author of this paper, who was an outsider and therefore was able to bring an independent view.

In addition to the interviews, in both schools the researcher observed classes to see how students interacted with their peers and teachers. Ideally, she would have conducted parallel observations in the tutorial centres; but since this was not possible, she borrowed the students' notes from the school work and the tutorial centres for comparison of approaches to teaching and learning. Permission to borrow these notes had been granted in advance not only by the students but also by their parents. The notes were not a complete substitute for lesson observation in the tutorial centres, but they did provide some information on what the students received in the tutorial centre that they did not receive at school. Table 3 summarises the total sample, using pseudonyms for the participants. It also indicates codes for the tutorial centres and tutors in those centres.

Table 3: Student Interviewees and their Tutorial Schools

\begin{tabular}{|l|c|c|c|c|c|}
\hline Name & Grade & Format of interview & School & Tutorial centre & Tutor \\
\hline Claudia & 11 & Individual and Group & A & TC1 & NA \\
\hline Inch & 11 & Individual and Group & A & TC1 & C \\
\hline
\end{tabular}




\begin{tabular}{|c|c|c|c|c|c|}
\hline Oscar & 11 & Individual and Group & A & TC2 and TC1 & $\mathrm{LCW}+\mathrm{C}$ \\
\hline Quiet & 11 & Individual and Group & A & TC2 and TC1 & $\mathrm{LCW}+\mathrm{L}$ \\
\hline Wong & 11 & Individual and Group & A & TC2 & $\mathrm{L}$ \\
\hline Britain & 11 & Individual and Group & A & TC2 & $\mathrm{L}$ \\
\hline Kitty & 10 & Individual and Group & B & TC1 & $\mathrm{C}$ \\
\hline Vanessa & 10 & Individual & $\mathrm{B}$ & TC1 & $\mathrm{C}$ \\
\hline Wendy & 11 & Group & $\mathrm{B}$ & TC1 & $\mathrm{C}$ \\
\hline Jasmine & 11 & Group & $\mathrm{B}$ & TC1 & $\mathrm{C}$ \\
\hline Tiffany & 11 & Group & $\mathrm{B}$ & TC1 & $\mathrm{C}$ \\
\hline Pamela & 11 & Group & $\mathrm{B}$ & TC1 & $\mathrm{C}$ \\
\hline Catherine & 12 & Group & $\mathrm{B}$ & TC1 & $\mathrm{C}$ \\
\hline Cathy & 12 & Group & $\mathrm{B}$ & TC1 & NA \\
\hline Cat & 12 & Group & $\mathrm{B}$ & TC1 & $\mathrm{C}$ \\
\hline Sixy & 12 & Individual & $\mathrm{B}$ & TC1 & $\mathrm{C}$ \\
\hline
\end{tabular}

\section{Marketing and Satisfaction of Students' Needs}

One of the keys to business marketing lies in the managers' ability to identify and satisfy customers' needs (Kotler and Armstrong 2013). This principle applies to tutorial centres as much as to other types of business. One question then is what senior secondary students' needs were not met by their schools that could be met by the tutorial centres. A related question, in line with a parallel business strategy, is whether the tutoring companies were able to create perceptions of needs through advertising and other means.

To structure analysis, it is useful to draw on Maslow's classic (1943) hierarchy of needs. At the most basic level are what Maslow called physiological needs, followed in order by safety needs, social needs, esteem needs, and self-actualisation needs. Various authors (e.g. Leigh 2011; Lucas 2010; Zhao 2010) have used this framework in the education sector, and the following paragraphs apply it to tutoring in Hong Kong. The analysis also contrasts the "push" for students who felt that they were inadequately served by the schools with the "pull" of the tutorial centres through their attractive activities.

\section{Basic educational needs}

The tutoring companies do not meet physiological needs arising from such demands as hunger and thirst. However, elements of what may be described as basic educational needs can be identified. Students had perceptions of threshold needs in quality and content of teaching, and reported that they went to tutors because their needs were not fully met by their regular teachers. This may be described as a "push". Several students stated that they lacked meaningful learning in school because of ineffective group discussion, lack of teachers' feedback, and irrelevant teaching contents. Britain and Wong complained that they were asked to copy throughout the whole lesson, which they found boring and unproductive. Britain felt that the teacher showed standard film clips, and she criticised her teacher's lack of focus on examination skills: 
Britain: I think school emphasises too much on textbook knowledge. They don't teach other things like creative thinking, writing skills, but tutors teach the others more...

Interviewer [I]: Meaning tutors focus on skills-teaching more?

Britain: Yes, teach you how to think and how to write.

I: So the tutorial centres focus on skills more?

Britain: Yes ...

I: Then it seems school and tutorial teaching are really different? Which one do you like more?

Britain: I am OK with both, but I think that school should focus on skills too, not only teaching textbook knowledge.

A more subtle situation was presented by Vanessa, who did not feel able to speak freely in her class despite the espoused aims of Liberal Studies:

I: OK, so, Liberal Studies is like a subject which seems to emphasise [critical] thinking...? Do you feel yourself thinking during Tutor C’s lessons? (Vanessa: nodding) You do?

Vanessa: I do, I think a lot.

I: Do you feel like thinking during Miss AY’s [school] class?

Vanessa: Not as much.

I: Why? What's the difference?

Vanessa: Cos in Miss AY's lesson, you have to be very careful on what would be right and wrong... You get tired after judging yourself for a while, then you don't want to talk anymore.

A different perspective was presented by Jasmine, who felt that the materials in her school were outdated and therefore a liability:

Jasmine: Tutor C's materials are more updated. In the textbook, the GDP [Gross Domestic Product] of China ranks $5^{\text {th }}$, but actually it is ranked $2^{\text {nd }}$ now. Then you would feel like what is mentioned in the textbook is wrong.

I: Cos it's some time ago.

Wendy: Yes, because it's issued in the past, so we can't believe all the data it covers, cos things have changed already, haven't they?

I: Is updated news important for Liberal Studies?

Jasmine: Hmm... it is somehow important... cos if you write something like GDP ranks the $5^{\text {th }}$, it will mark your essay wrong.

Wendy: In fact, everyone knows that the GDP of China ranks $2^{\text {nd }}$ already, how can you follow the textbook to write $5^{\text {th }}$ ? Yes, some data changed with time. If you follow the textbook directly, you may lose marks! So what to do if you really need to use the source information but what you've got in hand is wrong? Even in school, you can't have that updated information from teachers. For example, ... the fact that China has become the country with the highest carbon dioxide emission. You can never see such updates from school.

These critical comments reflect part of the "push" towards the tutorial centres. Although teachers could have provided updated information, according to Jasmine and Wendy they did not do so. On the "pull" 
side, the tutorial centres provided interesting video clips, summary notes and other materials. They also had a learning atmosphere in which all students were focused, perhaps because tutorial lessons cost money while regular schooling was free of charge. Further, the tutorial classes were in Chinese, the mother-tongue of the majority of respondents. This was particularly important to students in School B, which was an Englishmedium institution. It was less significant to counterparts in School A which was Chinese-medium.

\section{Safety needs}

The introduction of a subject calling for a shift from spoon-feeding pedagogy to critical thinking skills contributed to students' anxiety. Ho (2011) reported on a survey of 983 Grade 11 students in eight schools that found that $36.5 \%$ felt anxious about the shift in approaches. The tutorial centres built on the students' anxieties to enlarge their market.

Several interviewed students worried about the way in which the subject was implemented, with marking criteria that were unclear and untested. Oscar and Quiet were confused about what Liberal Studies aimed to do and how to study, and others were concerned about subjective marking of their papers. Jasmine and Tiffany said that they did not tell their teachers because they worried that the teachers would deduct marks. The students' lack of confidence caused them to seek more 'concrete' guidelines:

Jasmine: I remember that I got a big tick, with comments just copying from the exact wording from the public exam marking scheme!! The same wording in the four-marks range!

I: So it's direct copying?

Jasmine: Yes!

I: Then why don't you tell the teacher of your concerns?

Tiffany: We have to face her for two years!

I: Ahaha then?

Tiffany: If you irritate her, she will give you low marks afterwards.

Pamela: In fact, if she doesn't like you, she can give you no marks!

Jasmine: Cos in Liberal Studies... it's difficult to say... if the teacher doesn't think your point is a good point, she can hold back the marks. It's not Mathematics in which you are sure that you can get the marks as long as you got correct answer.

Oscar also felt that the teachers' marking lacked constructive feedback, and worried about the marking criteria:

Oscar: They only say ... 'not detailed enough' but they don't tell you what's not detailed enough... and like how to be more detailed. Sometimes I think school teachers mark our work in a self-contradicting way.... I remember like in the examination paper... there's one question asking us whether national strength is enhanced. After writing the advantages [of why it has increased], the teacher ask us to write the disadvantages as well. So it seems it's contradicting. 
The tutors portrayed themselves as authorities able to compensate for teachers' uncertainties and inexperience. They presented many examination-format questions, with sources from ASL past papers. They also told students how examination questions would be set - though in reality they could not know for certain since the first HKDSE examination had not yet been held. Britain and Wong indicated that every session taught by Tutor L commenced with an examination-format Liberal Studies question. Tutor C would go further to offer 'tips' that gave students a sense of certainty. The tips included suggestions on which questions would be likely to come up in which year - though again the tutors could not have a basis for prediction since Liberal Studies did not have a history at the HKDSE level.

The teaching of essay structure in a content-detached and formulaic way gave students a strong feeling of clarity with the assumption that the approach would guarantee good grades. Wong and Britain remarked on Tutor L's teaching of essay structure:

Wong: He teaches us with the example of hamburger, bread and sauce structure.

Britain: He uses this to explain the structure of the question, understanding the question, and example. 'Bread' refers to the question; 'sauce' refers to the understanding, explanation of the question, examples; and in the end you 'wrap it up'. He gives you these... and he repeats this in every question. Also, he gives you another [symbol] for your self-checking [of your essay performance]: with 'man, goods, money'. He says for every Liberal Studies essay-answer, you must include these three things.

A further way through which the tutors promoted a sense of safety was a mock examination. The tutors told the students that because the tutors looked across schools, they could gauge standards more effectively. Within schools, the students were told, teachers would only see a small part of the pool. Students reported that the mock examination could better benchmark their ability in the whole pool of public examination candidates.

Students were also impressed by the sense of authority in Tutor C's course materials, and the declaration that almost $80 \%$ of her students scored A's in the examination. This approach increased the feeling of safety in the face of uncertainties. Vanessa's remarks provided an example:

I: I see... so you want to know more about examinations. What makes you think that Tutor $\mathrm{C}$ can provide you with the examination information?

Vanessa: I think that like, being a tutorial teacher, with a lot of advertisements on buses and everywhere, she must have something special.

I: Something special, for examination?

Vanessa: Yes. And she always says that almost $80 \%$ of her students got A's in examination, so then I would like to try her lessons. Well, I haven't got A in exam, but I think that I did get some hints of the questions.

Wendy remarked that she saw question-types in the tutorial centre that had never been covered in class, and that the experience had shocked her. She particularly mentioned questions that began 'If you were ...”, and expected students to imagine themselves in particular situations. Wendy added that her teacher 
was unable to explain how to improve her writing. She felt that the teacher was not prepared for the lesson, and that she did not receive useful feedback.

Kitty, in the same school, also noted that students did not feel safe to seek help from school teachers, maybe out of fear of being seen as a "teacher's pet”:

Kitty: for Liberal Studies ... hmm... I think that my classmates dare not to ask questions. But maybe in Tutor C's class ... I see students dare asking questions...

I: Hmm... But how so? In fact, I think school teachers are nice, aren't they?

Kitty: Yes, I think so too.... I always chat with teachers too but I don't know.... Somehow I feel like classmates refuse asking teachers questions or going to see teachers. I don't know why. It's strange...

I: Are you the type of student who is willing to communicate with teachers?

Kitty: Yes, I am. But then maybe many classmates would speak behind my back saying that I approach teachers purposefully to pretend a good student... something like this....

\section{Social needs}

In contrast to the complaints that teachers were unapproachable, students received great satisfaction from the channels of connection with the tutors. Some of the communications were on Facebook, which was very popular among students and not a medium that teachers would normally consider. Students were also able to reach Tutor C via e-mail. Students added that Tutor C would arrive early and stay behind after class for questions. This was part of the "pull" of the tutorial centre.

Kitty: She is nice and asked us to tell her afterwards if we can't jot down all the points.... I think what she is good about would be ... her personality. I think it's about her as a person.... She gets close to students... like... if you go ask her questions... she won't be too rejecting.... She will be in the centre even till 8 or $9 \mathrm{pm}$.

I: What do you mean by 'in the centre'?

Kitty: She will stay in a room after lesson. We can sign up to ask her questions after lesson.

Vanessa would intentionally arrive early to chat with Tutor C. Moreover, when Vanessa showed Tutor C her school test paper, the tutor advised her how to improve:

I: As far as I know, students are very distant from the tutors in the large-scale tutorial classes...

Vanessa: No.

I: Oh, why not?

Vanessa: Hmm... I meet her before lessons. Usually I leave school very early when school off to tutorial because it's free of charge to meet her before lesson starts. [skip]

I: I see... OK, let's go back and see why didn't you feel yourself distant from the tutor?

Vanessa: When you arrive early, you can always talk to her.

I: She will come in the classroom earlier? 
Vanessa: Yes... She comes in earlier because she reserves the time for us to ask her questions... But if there are no particular questions on Liberal Studies, we will just chat and talk ahaha.

I: Oh, so you will be chatting on casual stuff?

Vanessa: Yes.

I: Are students eager to talk to her?

Vanessa: Some students do that, but for those who always sit at the back, they won't.

I: So you are one of those who would talk to her ...

Vanessa: Yes. I talk a lot ahaha

A further social dimension concerned peer relationships. The students went to the tutorial centre together, and to some extent this contributed to peer support in their studies.

\section{Self-esteem needs}

In order to enhance students' feeling of superiority from enrolling in their classes, tutors gave them privileged keys to materials. Kitty mentioned that to understand the booklet distributed by Tutor C, students had to get the passwords from Tutor C's lessons. This not only gave them a sense of superiority, but also retained them in the classes:

I: But people know about it once she issues the booklet, don't they?

Kitty: Yes, in fact. But there are some secret codes.

I: Secret codes?

Kitty: Yes, what X-Y something... There are some missing symbols... She has written out some before...

I: So that means you have to add back the codes if you want to understand the booklet?

Kitty: Yes yes, it’s hilarious. Oh, like these [the booklet]! So some formula, some symbols...

Students also felt that they were gaining special knowledge in the types of materials that were not covered by school teachers:

I: What is the best thing that you like about Tutor C?

Jasmine: I like the news she used. Those news are special. For example, she talked about the strengths of China. We will go down to see 'resources'. Usually what we see is about land, people; but she will tell us about "Chinese rare earths”. So I feel like, people who are not in Tutor C's class won't know about this. Only I got such kind of special information, cos school teachers have not mentioned it.

\section{Self-actualisation needs}

Self-actualisation involves the idea of self-development and realisation to the full potential (Maslow 1943: 382; Lucas 2010: 219-222). Some students displayed strong self-motivation. Inch desired more homework for practice, even though she already perceived herself as a high-achiever. Vanessa also sought more challenging supplementary information from tutors. 
Tutor C's marking was described as very strict. She stated that she would only give $80 \%$ of the true grade to students' assignments. However, these students appreciated Tutor C's strictness. They believed that Tutor C could better gauge the true marking standard and therefore their ability, even though they might fail Tutor C's assignments. Students who had high self-actualisation goals would be more comfortable receiving lower grades with "more objective" marking. Students were told by the tutors that school marking was not done according to the appropriate standard. Kitty reported as follows:

Kitty: She said that in schools... usually teachers would give marks in a loose way but in fact the public examination markers would give out marks in a strict way... She said that her standard is the public examination standard... She said that school teachers have been lenient to us.

I: Why so?

Kitty: She said that ... hm... schools like ours, traditionally famous schools... like... she read my homework/test paper, she said that ... donno why, teachers will give a better score to us, but if it is she who marks the scripts, she would definitely give it a fail.

I: So, it's like the test paper you gave her last time?

Kitty: Yes, she would think that it was not good

I: She said that it's not good?

Kitty: She didn't respond to me directly, but she mentioned it during her lessons saying what the traditionally famous schools are doing.

\section{Further dimensions of impact}

Although tutorial teaching may be effective for some students, it may impact negatively on dimensions of learning, schooling experiences, and wider values. Each of these domains is here considered in turn.

Beginning with the nature of Liberal Studies learning, as noted by Fung et al. (2011: 187) the official guidelines stated that work should be assessed 'in terms of how knowledge and understanding are organised by the learner - not the amount of knowledge gained and understood'. However, much of what tutors taught as "techniques" contradicted this approach. In order to present their teaching as clear, they developed formulaic approaches which included point-marking systems.

I: (seeing Inch writing 'memorising definition') So, ... 'memorise definition' ... Is it useful?

Inch: At least you can get a few marks.

I: Hmm... Will the exam question ask you about definition?

Claudia: Not in a straightforward way. But sometimes when you answer a question, you need to give the definition together with your personal opinions.

I: Then, when do you know you need to give definitions?

Claudia: Cos like... about 'national strength'... You will know what definitions are there in this topic. So when you give definition, you can get 1-2 marks. Together with cases appeared in textbook, you will get more marks when you quote the cases.

I: Does it mean that, as long as you provide definition, you can get at least a few marks?

Inch and Claudia: Yes. 
I: Hmm... So it makes definitions useful. You need to memorise then.

Inch and Claudia: Yes, need to.

Also, the digested news supplied by the tutors reduced the need for students to research by themselves, which went against the idea of 'learning to learn'. And the strong emphasis on marks in the tutorial centres led students to feel that the main purpose of the work was to compete for grades. This was clearly inconsistent with the idea of education for whole-person development.

The dissonance with the school also undermined that side of students' lives and caused them to lose learning opportunities at school. Vanessa refused to do school homework when she did not perceive it as fitting the tutor's recommended approach. She also focused on the topics in Tutor C's lessons rather than on those presented by her teacher. When the tutor had already covered topics that were taught at school, Vanessa found school boring and switched off. Kitty indicated that the tutor told students that the school approach was inappropriate and that the tutor's was closer to the demands of the examination. Such devaluing of school practice reduced her trust in school education.

Turning to the business values imparted, many teachers, government personnel and members of the general public were critical of the ways in which the tutorial centres used teenage language to attract clients, feeling that much of this language was inappropriate to an educational setting. Similar remarks might apply to the curriculum content of the tutorial classes, which included gossip magazines. However, the tutorial centres and the teenagers themselves might have countered that the criticisms by teachers and others just reflected their conservatism which was in fact at variance with the spirit of Liberal Studies' encouragement of open attitudes and freedom of expression.

On a different tack, teachers might have felt uneasy about ways in which tutors extracted information from the schools in order to build up their own resource banks. One strategy was to ask students to bring their schools' internal test papers in order to gain a 'useful' Liberal Studies booklet in exchange. As reported by Kitty when asked whether and how the tutor gained test papers and questions from different schools:

Kitty: Yes, she has taken one of our questions, too.

I: But it's from students.

Kitty: Yes, should be from students. It's like this ... well... cos you know she has made a booklet for Liberal Studies. She said that if you want to take the booklet, you have to submit three Liberal Studies questions from your school, plus introduce a new student, plus write down 10 related key concepts next to each of the questions you submit to her. So I would need to submit a question plus 10 key concepts to her ... like this ... yes.

I: Have you submitted?

Kitty: No, no, I haven’t. I ignored her. I think that it doesn’t mean I will get better marks in Liberal Studies even if I get the booklet. There's only questions [in the booklet].

I: What is the booklet about actually?

Kitty: She hasn't showed any sample booklet to us, but sometimes in her lessons she will show us some pages, and she said that we must do all those submissions to her for the booklet. 


\section{I: What is inside the booklet? News?}

Kitty: No, the booklet is a collection of all the Liberal Studies papers from all the traditionally-famous schools. She said that she has amended a bit on the content and that she can't let others know about this... But I doubt the usefulness of the booklet, so I haven't taken it.

Some educators might be disquieted that Kitty saw the tutorial centre's business mode as acceptable. Her reason for not getting the booklet was that she did not consider it useful rather than that it could only be obtained through a questionable business practice. Kitty was also very accepting of other dimensions of advertising during lessons and the offer to students who had just taken a mock examination of $\$ 50$ coupons for the next mock examination.

Other students reported on the mechanisms for recruiting students. Claudia, for example, first attended the Liberal Studies tutorial class because she was already attending classes in Economics and Mathematics, and the company indicated that she could have trial Liberal Studies lessons free of charge. Other students reported that it was common to receive discounts if they recruited their classmates.

\section{Teaching, Learning and Assessment}

Understanding of the patterns presented above may be assisted by return to some of the core elements of Liberal Studies design and by reference to the wider literature. Dimensions include pedagogical approaches and modes of assessment.

Beginning with pedagogical approaches, Hong Kong teachers’ perspectives on Liberal Studies have been investigated by Stapleton (2011). Aiming to find out how teachers understood the concept of critical thinking, Stapleton noted that many teachers focused just on the ability to analyse issues from multiple perspectives. He remarked (p.21) that the conceptions "were incomplete and in many cases disturbingly narrow”. Aspects such as critical thinking as the habit of mind lacked attention.

The dominant pedagogy in School A matched this finding. As reported by the students interviewed, and as evident in the lessons observed, many Liberal Studies students were asked to learn through traditional pen-and-paper note taking and one-way lecturing which differed little from the styles in other subjects. Students in School A stated that they seldom held confrontational dialogues with teachers or peers, and that few group discussions were organised. One reason seemed to be that the teachers feared loss of control in classroom discipline, and Liberal Studies thus became content-led. Little evidence was found of effort to develop students as change agents, and instead the dominant expectation was that students would follow instructions from teachers.

When critical thinking is seen as equivalent to multiple-perspectives thinking, drilling through lecturing and students' individual practice becomes not only possible but perhaps also efficient. The tutorial centres recognised this, and developed a product which found a ready market. Even at school, it appears that many teachers and students expected the learning outcomes from Liberal Studies to remain intellectual written demonstrations of thoughts rather than personal dialogues with teachers and transformation of action. Of course Hong Kong has much diversity among both its teachers and its students, and no doubt some teachers 
and students did achieve the broader goals of Liberal Studies. Others, however, remained in the traditional modes of pedagogy.

In this connection, it is useful to note Kennedy's (2005: 1) remarks in a wider context about "the mysterious gap between reform ideals and everyday teaching”. Although her principal focus was on the USA, it could also have relevance to Hong Kong. Kennedy noted five possible reasons for the gap (p.13), namely that:

- teachers need more knowledge or guidance in order to alter their practices;

- teachers hold beliefs and values that differ from those of the reformers and that justify their current practices;

- teachers have dispositions that interfere with their ability to implement reforms;

- the circumstances of teaching prevent teachers from altering their practices; and/or

- the reform ideals themselves may be unattainable or may actually impede practice.

The question of the balance of these possibilities in Hong Kong classrooms is beyond the scope of the present paper, but the list is useful as a pointer to possible explanations why at least some of the classroom teaching for Liberal Studies remained in the old mould. The students' perspectives were also shaped by the traditions of schooling and by pedagogic styles in other subjects. The tutorial centres offered a way to remain in these traditions and thus to have a safety net when experiencing the different approaches of the teachers who did move beyond the old mould.

Elaborating on the clash between old and new, the intended reform stressed interdisciplinarity and an issue-enquiry approach which was expected to stimulate students' curiosity by situating learning tasks in reallife situations. Law (2010) observed that many Hong Kong teachers over-emphasised mechanical procedures, with rigid attention to recommended forms of learning process including writing, reflection and oral presentations that actually decontextualised students' learning. In line with this, the interviewed students in School B reported that they did engage in group discussions but did not feel satisfied with their learning. They complained that they lacked feedback from teachers, and felt that they engaged in discussions for the sake of discussions. In this context, they valued the tutors' alternative approach even though it only stressed individual thinking practices. The tutors avoided the discouraging act of asking students to engage in activities which the students did not perceive as adding value in learning. Instead, the tutors gave students immediate feedback on their individual practices. The teachers of these students did not seem to be able to manage an issue-enquiry learning approach in a convincing way. In contrast, the students perceived the mass tutoring to be better targeted with clearer feedback.

A further question is how far the SBA component functioned as a safeguard against Liberal Studies becoming dominated by teacher-centred pedagogies. As Hill and Wan (2006: 4) pointed out, the use of SBA may both increase the validity and reliability of assessments, and act as a 'positive backwash effect on teaching and learning' by diverting learners' attention from drilling for examination to learning through process. Again, however, the SBA component had disappointing dimensions. Yu (2009: 29) observed that: 
In Hong Kong, many teachers do not have the skills and experiences in instructing and assessing generic skills. It seems that there is a perceived conflict with traditional curriculum and instructional methods. The use of assessment tools such as rubric and portfolio is not common. Well-established assessment procedures and tools are not adequate at the moment.

Such skills can of course be developed, and Yu was writing during the very early stages of Liberal Studies implementation as a compulsory subject. Of relevance to this paper, however, is that SBA only comprised $20 \%$ of the total assessment for Liberal Studies. And in any case, the curriculum guide (CDC and HKEAA 2007: 135) stated that the students' final SBA grades would be statistically moderated according to the students' performance in the public examination. This announcement damaged the legitimacy of SBA, weakening the extent to which it could act as a counterbalance to examinations.

\section{Conclusions}

This paper is concerned with the operation and roles of market-driven services that parallel the provision of public education. Although it focuses only on Hong Kong, it has wider relevance to the expanding phenomenon of shadow education, which is itself part of the broad shift of balances towards privatisation associated with neoliberalism. On the one hand the paper shows a "push" towards external private-sector support when students felt that their schools did not meet all their needs; and on the other hand it identifies a "pull” from the tutorial centres that identified and met the students' perceived needs and to some extent manipulated variables to maintain and expand demand. Such factors are likely to be increasingly evident in Western Europe, North America and other regions in which commercialised shadow education is growing (Bray 2011; Burch 2009; Davies and Guppy 2010; Diskin 2010; Silova 2010).

The paper also shows that tutoring in the shadow sector can subtract as well as supplement. Some practices of the tutorial centres in Hong Kong undermined the effectiveness of schooling. Similar patterns are evident elsewhere, though have not been demonstrated in quite the way that has been done in this paper. The observation may be linked to Mazawi's (2013: 45) remark, quoted earlier, that "the public and private sectors are intertwined along complex articulations”. It may also be linked to the remarks of Ball and Youdell (2008: 98) about parenting magazines that "thrive on both the commercial exploitation of anxiety and childhood generally as a new market opportunity" and that "offer advice, but also create new desires and fuel fears". Like the publishers of parenting magazines around the world, the tutoring companies in Hong Kong aimed to stimulate as well as to satisfy demand. They exploited anxiety, especially among students but probably also among parents, and offered advice that to some extent alleviated the anxiety but in other ways created new desires and fuelled fears.

The context for analysis in this paper has been a new subject with its distinctive features. As noted by Deng (2009: 290), the objectives of Liberal Studies in Hong Kong were in "stark contrast" to those of conventional subjects such as Mathematics and Chemistry. As such, Liberal Studies should not have been compatible with the examination cramming which formed a major focus of the mass tutoring companies. The 
fact that only 16.6\% of the Grade 12 students sampled by Bray et al. (2012) were receiving tutoring in Liberal Studies, compared with $80.3 \%$ in English, $40.5 \%$ in Chinese and $29.4 \%$ in Mathematics, may indicate that the curriculum designers were to some extent successful in their goal. However, it is arguable that $16.6 \%$ was still a large number, and clearly the goal had not been totally achieved.

Moreover, as recounted by the interviewees some dimensions of the work of the marketised shadow sector altered the curriculum received and changed students' views and expectations of their teachers. The tutorial centres facilitated and encouraged a formulaic approach to examinations which included memorisation of definitions and content-detached structuring of essay questions. Indeed it is arguable that for some students the tutorial centres subverted the subject to the extent that it was no longer Liberal Studies in the sense of liberating the students' minds. Students were also encouraged to see their teachers as lacking a cutting edge and inadequately informed on the overall picture of assessment demands in the forthcoming examinations. One student refused to do school homework when it was not perceived to fit the tutor's recommended approach; and when the school turned to topics that had already been covered by the tutor, the student considered it boring and switched off. At the same time, more positively, the tutorial centres clearly did meet some needs which were not being met by the schools. Not all of their work was cramming in the negative sense, and the centres assisted students with study skills and provided supplementary resources. They also strengthened the confidence of some students.

Methodologically, this paper has focused on the experiences of a small sample of the students who sought tutoring. These students had their own personal characteristics and motives, and did not represent all students. The study benefitted from approaches used in “insider research" (Sikes \& Potts 2008) while recognising limitations and taking account of both student-to-student and student-to-teacher dynamics in the recording of perspectives. It would be useful to enlarge the sample to include students from a wider range of schools and tutorial centres. The sample of two schools did cover the range of ability groups, classified as Bands 1, 2 and 3 in the Hong Kong system, but of course every school has its own dynamics and institutional culture. Nevertheless, discussions with teachers and students from other schools, and triangulation with other research (Zhan et al. 2014), suggested that as a group these students were not atypical. Similar remarks may be made about the teachers. Certainly the teaching force had much diversity, but there is no reason to believe that the teachers of this group of students were especially unusual. And the tutors of these students may be taken as illustrative of the part of the commercialised sector that highlights "star tutors" and particularly advertises its competence in providing tips for examination success.

Noting the existence of both positive and negative dimensions of the marketised tutoring, analysts might be tempted to draw up a balance sheet to gain an overall view of the desirability or otherwise of the phenomenon. Any conclusion that might be reached would be subjective, and would not be based on statistically precise evaluations of the positive and negative dimensions. Nevertheless, the fact that the overall balance could be negative suggests that teachers, government personnel and other stakeholders should consider ways in which regular schooling can be improved to make mass tutoring less necessary in the eyes of the students. Indeed arguably this should be considered even if the overall balance is positive, because then it 
could become even more positive. Teachers and others could commence by looking at the supplementary sector for innovative ideas and client-oriented (or at least student-oriented) approaches. Assuming that the structures and objectives of Liberal Studies are retained, this paper highlights students' desires for clarity in the modes of assessment and benchmarking of schools, classes and individuals within the total pool. The study also suggests that further focus is needed on the processes of teaching to achieve the spirit and content envisaged by the architects of the subject. Some of these objectives might be achieved relatively easily as successive cohorts proceed through the system and greater experience is acquired. Other components would require considerable effort, especially since Liberal Studies remains different in format from other subjects and since traditional patterns of pedagogy and assessment remain tenacious. In this respect, patterns in Hong Kong again have parallels in other parts of the world (Kennedy 2005; Schweisfurth 2013).

The other side of the equation concerns the tutoring companies. These enterprises exist for profitmaking purposes, and have shown that indeed education can be marketised alongside public provision. Hong Kong is sufficiently prosperous to have a significant number of families able to afford the services; and in any case, the business model of mass provision allows the companies to offer tutoring at relatively modest prices. Hong Kong’s shadow education industry has become very visible and well entrenched, and will not simply evaporate even if the schools do improve their teaching of Liberal Studies. Thus the industry is likely to continue to advertise heavily and to devise multiple strategies to secure and retain clients.

As noted with reference to the wider, international picture, some dimensions of the private-sector work may be viewed positively. Teaching and learning is a personalised process, and no single model can suit everybody. At school, students have little or no choice in their teachers; but in the marketplace they have considerable choice, and the existence of the tutoring companies therefore allows at least some students to gain modes of support which they consider suited to their temperaments and skill sets. If such tutoring leads to an overall net gain in learning, then arguably the whole society as well as the students themselves benefits. If the tutoring is at the cost of some elements of in-school learning, the overall balance sheet may be less positive but can still be acceptable.

Finally, insofar as the tutorial companies meet at least some needs that could be met by the schools themselves, the companies provide a model from which teachers can learn. Thus, the shadow sector is not necessarily just parasite. It can also be a source of ideas and inspiration for teachers who also consider their students' needs more carefully. Consideration of students' perspectives, perhaps in a framework of their perceived needs as outlined in this paper, could be a starting point of relevance to teachers and administrators in other societies as well as in Hong Kong. Meanwhile, the paper indeed shows the complex intertwining of public and private highlighted by Ball and Youdell (2008: 98) and Mazawi (2013: 45). Balances between public and private are likely to continue to shift worldwide, and the Hong Kong example may provide an indicator of future scenarios for other societies in which the shadow education sector is expanding. 
Acknowledgement: The research reported in this paper was conducted within the framework of work supported by the General Research Fund (GRF) of the Hong Kong Research Grants Council (RGC), project 741111. The authors also express appreciation to the students in the schools researched, and to five anonymous reviewers.

\section{References}

Apple, M.W. (2006) Educating the "Right" Way: Markets, Standards, God, and Inequality. $2^{\text {nd }}$ edition. New York: Routledge.

Askew, M., Hodgen, J., Hossain, S. \& Bretscher, N. (2010) Values and Variables: Mathematics Education in High-performing Countries (London: Nuffield Foundation).

Aslam, M. \& Atherton, P. (2012) The 'Shadow' Education Sector in India and Pakistan: The Determinants, Benefits and Equity Effects of Private Tutoring. ESP Working Paper 38 (Budapest: Education Support Programme, Open Society Foundations).

Ball, S.J. \& Youdell, D. (2008) Hidden Privatisation in Public Education. Brussels: Education International.

Baştürk, S. \& Doğan, S. (2011) Evaluations of cram school mathematics teachers on cram schools. EInternational Journal of Educational Research, 2 (3): 68-86.

Bourdieu, P. (1998) Practical Reason: On the Theory of Action. Cambridge: Polity Press.

Bray, M. (1999) The Shadow Education System: Private Tutoring and its Implications for Planners (Paris: UNESCO International Institute for Educational Planning).

Bray, M. (2009) Confronting the Shadow Education System: What Government Policies for What Private Tutoring? (Paris: UNESCO International Institute for Educational Planning).

Bray, M. (2011) The Challenge of Shadow Education: Private Tutoring and its Implications for Policy Makers in the European Union (Brussels: European Commission).

Bray, M., Kwo, O., Lykins, C., Mang, E., Wang, D. \& Zhan, S.L. (2012) Private supplementary tutoring: Scale, nature and implications for secondary schooling in Hong Kong. GRF project (2011-2013). Hong Kong: Faculty of Education, The University of Hong Kong.

Bray, M., \& Lykins, C. (2012) Shadow Education: Private Supplementary Tutoring and its Implications for Policy Makers in Asia. Mandaluyong City: Asian Development Bank, and Hong Kong: Comparative Education Research Centre, The University of Hong Kong.

Bray, M., Mazawi, A.E. \& Sultana, R.G. (eds) (2013) Private Tutoring across the Mediterranean: Power Dynamics and Implications for Learning and Equity. (Rotterdam: Sense).

Bregvadze, T. (2012) Analysing the shadows: private tutoring as a descriptor of the education system in Georgia. International Education Studies, 5 (6), s80-89.

Buhagiar, M.A. \& Chetcuti, D.A. (2013) The private tuition phenomenon in Malta: Moving toward a fairer education system. In M. Bray, A.E. Mazawi \& R.G. Sultana (eds), Private Tutoring across the Mediterranean: Power Dynamics and Implications for Learning and Equity (Rotterdam: Sense), 129149.

Burch, P. (2009) Hidden Markets: The New Education Privatization (New York: Routledge).

Curriculum Development Council \& Hong Kong Examinations and Assessment Authority (2007) New Senior Secondary Curriculum and Assessment Guide (Secondary 4-6) - Liberal Studies. (Hong Kong: Author).

Davies, S. \& Guppy, N. (2010) The Schooled Society: An Introduction to the Sociology of Education. $2^{\text {nd }}$ Edition (Toronto: Oxford University Press).

Deng, Z. (2009) The formation of a school subject and the nature of curriculum content: an analysis of liberal 
studies in Hong Kong. Journal of Curriculum Studies, 41 (5), 585-604.

Diskin, K. (2010) Private Tutoring: An Intersection of Economic Interests and Social Capital. PhD dissertation, Walden University.

Education Commission (2000) Learning for Life, Learning through Life: Reform Proposals for the Education System in Hong Kong (Hong Kong: Education Commission).

Fung, C.L. \& Yip, W.Y. (2010) The policies of reintroducing Liberal Studies into Hong Kong secondary schools. Educational Research for Policy and Practice, 9 (1), 17-40.

Fung, Y., Tang, T. \& Chan, C.C. (2011) Learning and Teaching Liberal Studies: Theory and Practice (Hong Kong: Open University of Hong Kong Press).

Gomes, C.A., Mariano, F., de Oliveira, A., Barbosa, A., de Sousa, J.H.B. \& Friedrich, N. (2010) Reforço escolar: gastos e desigualdades sociais. Revista Brasileira de Estudos Pedagógicos, 91 (227), 55-74.

Harvey, D. (2007) A Brief History of Neoliberalism. Oxford: Oxford University Press.

Hill, P.W. \& Wan, T.W. (2006) Assessment Reforms in Hong Kong. Paper presented at the 32nd IAEA Conference, Singapore. http://www.iaea.info/documents/paper_1162a2725.pdf

Ho, S. (2011) Early exam jitters over new subject. The Standard, 28 March.

Ireson, J. \& Rushforth, K. (2011) Private tutoring at transition points in the English education system: its nature, extent and purpose. Research Papers in Education, 26 (1), 1-19.

Japan, Ministry of Education \& Training (2008) Report on the Situation of Academic Learning Activities of Children. Tokyo: Monbukagahusho Hokokusho. [in Japanese]

Johnson, B. \& Christensen, L. (2012) Educational Research: Quantitative, Qualitative, and Mixed Approaches. $4^{\text {th }}$ Edition (Los Angeles: SAGE).

Kassotakis, M. \& Verdis, A. (2013) Shadow education in Greece: Characteristics, consequences, and eradication efforts. In M. Bray, A.E. Mazawi \& R.G. Sultana (eds), Private Tutoring across the Mediterranean: Power Dynamics and Implications for Learning and Equity (Rotterdam: Sense), 93113.

Kennedy, M.M. (2005) Inside Teaching: How Classroom Life Undermines Reform (Cambridge, MA: Harvard University Press).

Kim, K.K. (2010) Educational equality. In C. J. Lee, S. Y. Kim \& D. Adams (eds), Sixty Years of Korean Education (Seoul: Seoul University Press), 285-325.

Kotler, P. \& Armstrong, G. (2013) Marketing: An Introduction. $11^{\text {th }}$ Edition (New Jersey: Prentice Hall International).

Kwo, O. \& Bray, M. (2011) Facing the shadow education system in Hong Kong. IIAS Newsletter. Leiden, Netherlands, International Institute for Asian Studies, Leiden University, 56: 20.

Kwok, P. (2004). Examination-oriented knowledge and value transformation in East Asian cram schools. Asia Pacific Education Review, 5 (1), 64-75.

Kwok, P. (2009). A cultural analysis of cram schools in Hong Kong: Impact on youth values and implications'. Journal of Youth Studies, 12 (1), 104-114.

Lakes, R.D. \& Carter, P.A. (2011) Neoliberalism and education: an introduction. Educational Studies, 47 (2), 107-110.

Law, T. Y. (2010) The Rationale and Model of Inquiry Learning. Hong Kong: Hong Kong Institute of Education.

Lee, C. (1996) Children and Private Tuition. Youth Poll Series 34 (Hong Kong: Hong Kong Federation of Youth Groups).

Lee, C.J., Park, H.J. \& Lee, H. (2009) Shadow education system. In G. Sykes, B. Schneider \& D.N. Plank 
(eds), Handbook of Education Policy Research (New York: Routledge), 901-919.

Leigh, J. (2011) A reflective assessment of my practice as a geography teacher in inclusive higher education. British Journal of Educational Research, 1 (2), 69-83.

Lucas, R.W. (2010) Energize Your Training: Creative Techniques to Engage Learners (Lanham, Maryland: American Society for Training \& Development).

Maslow, A.H. (1943) A theory of human motivation. Psychological Review, 50 (4), 370-396.

Mazawi, A.E. (2013) Grammars of privatization, schooling and the "network state”. In T. Szkudlarek (ed), Education and the Political: New Theoretical Articulations (Rotterdam: Sense), 41-60.

Mori, I. \& Baker, D. (2010) The origin of universal shadow education: what the supplemental education phenomenon tells us about the postmodern institution of education. Asia Pacific Education Review, 11 (1), 36-48.

Morris, P. \& Adamson, B. (2010) Curriculum, Schooling and Society in Hong Kong (Hong Kong: Hong Kong University Press).

Napporn, C. \& Baba-Moussa, A. R. (2013) Accompagnement et soutien scolaires: l'expérience béninois. Revue international d'éducation - Sèvres, 62, 1-10.

Ng, F.H.C. (2006) Teacher knowledge construction in applying the issue-enquiry approach in Liberal Studies: A study of tensions and possibilities. Paper presented at the conference on "School improvement and university-school partnership”, The Chinese University of Hong Kong. Available http://www.fed.cuhk.edu.hk/ cthk/paper/a5.pdf accessed 10 January 2013.

Ngai, A., Chan, S.C. \& Cheung, S. (2013) Private Tutoring of Primary and Secondary School Students in Hong Kong (Hong Kong: Hong Kong Federation of Youth Groups).

Odhiambo, J.O. (2009) Effects of Remedial Lessons on Academic Achievement of Students in Public Secondary Schools in Nairobi West District, Kenya. MEd dissertation, Nairobi: The Catholic University of Eastern Africa.

Osborne, J.E. (1990) Some basic existential-phenomenological research methodology for counselors. Canadian Journal of Counselling, 24 (2): 79-81.Poon, K.S. (2011) Over 10\% of students enrolling in Liberal Studies tutoring. Sing Tao Daily, 4 July. [in Chinese]

Putnam, R.D. (2000) Bowling Alone: The Collapse and Revival of the American Community. New York: Simon and Schuster.

Privatisation in Education Research Initiative [PERI] (2013) About us. http://www.periglobal.org/page/aboutperi accessed 24 August 2013.

Roesgaard, M. (2006) Japanese Education and the Cram School Business: Functions, Challenges and Perspectives of the Juku. (Copenhagen: Nordic Institute of Asian Studies Press).

Safarzyńska, K. (2013) Socio-economic determinants of demand for private tutoring. European Sociological Review, 29 (2), 139-154.

Schweisfurth, M. (2013) Learner-centred Education in International Perspective: Whose Pedagogy for Whose Development? (London: Routledge).

Sikes, P. \& Potts, A. (2008) Closing thoughts. In P. Sikes \& A. Potts (eds), Researching Education from the Inside: Investigations from Within (London: Routledge), 177-180.

Silova, I. (2010) Private tutoring in Eastern Europe and Central Asia: policy choices and implications. Compare: A Journal of Comparative and International Education, 40 (3), 327-344.

Silova, I., Būdienè, V. \& Bray, M. (eds) (2006) Education in a Hidden Marketplace: Monitoring of Private Tutoring (New York: Open Society Institute). 
Sobhy, H. (2012) The de-facto privatization of secondary education in Egypt: a study of private tutoring in technical and general schools. Compare: A Journal of Comparative and International Education, 42 (1), 47-67.

Song, K.O., Park, H.J. \& Song, K.A. (2013) A cross-national analysis of the student- and school-level factors affecting the demand for private tutoring. Asia Pacific Education Review, 14 (2), 125-139 .

Southgate, D.E. (2009) Determinants of shadow education: A cross-national analysis. PhD dissertation (Ohio: Ohio State University).

Stapleton, P. (2011) A survey of attitudes towards critical thinking among Hong Kong secondary school teachers: implications for policy change. Thinking Skills and Creativity, 6 (1), 14-23.

Steger, M.B. \& Roy, R.K. (2010): Neoliberalism: A Very Short Introduction. Oxford: Oxford University Press.

Stevenson, D.L. \& Baker, D.P. (1992) Shadow education and allocation in formal schooling: transition to university in Japan, American Journal of Sociology. 97 (6), 1639-1657.

Torres, C.A. (2009) Education and Neoliberal Globalization. New York: Routledge.

UNESCO (2012) EFA [Education for All] Global Monitoring Report 2012: Youth and Skills - Putting Education to Work. Paris: UNESCO.

Yu, T.W. (2009) The moderation of Liberal Studies school based assessment scores: how to ensure fairness and reliability? International Education Studies, 2 (4), 91-98.

Ventura, A. \& Gomes, A. (2013) Supplementary education in Brazil: diversity and paradoxes. In J. Aurini, S. Davies \& J. Dierkes (eds.), Out of the Shadows: The Global Intensification of Supplementary Education (Bingley: Emerald), 129-151.

Ward, S. (2013) Education policy and the marketisation of education. In S. Ward (ed.), A Student's Guide to Education Studies, $3^{\text {rd }}$ edition (New York: Routledge), 3-11.

Williamson, J. (2009) A short history of the Washington Consensus. Law and Business Review of the Americas, 15 (1), 7-23.

Zajda, J. (ed.) (2006) Decentralisation and Privatisation in Education: The Role of the State (Dordrecht: Springer).

Zeng, K. (1999) Dragon Gate: Competitive Examinations and their Consequences. London: Cassell.

Zhan, S., Bray, M., Wang, D., Lykins, C. \& Kwo, O. (2014) The effectiveness of private tutoring: students' perceptions in comparison with mainstream schooling in Hong Kong. Asia Pacific Education Review, 15 in press. DOI 10.1007/s12564-013-9276-7

Zhang, Y. (2011) The Determinants of National College Entrance Exam Performance in China - With an Analysis of Private Tutoring. PhD dissertation, Columbia University.

Zhao, J.M. (2010) The problems and countermeasures about teachers' encouragement in higher vocational colleges: a perspective of Maslow's hierarchy of needs theory. Higher Vocational Education, 19 (1), 62-65. [in Chinese]

\section{Biographical notes}

Claudia Chan is a Liberal Studies teacher in a Hong Kong secondary school; e-mail: claudiayuenki@gmail.com. Her research work has been conducted in association with the Shadow Education Special Interest Group (SIG) of the Comparative Education Research Centre at the University of Hong Kong.

Mark Bray is UNESCO Chair Professor in Comparative Education at the University of Hong Kong; e-mail: mbray@hku.hk. He has taught at this university since 1986, but between 2006 and 2010 took leave to work in Paris as Director of UNESCO's International Institute for Educational Planning (IIEP). 